\title{
Chromosomal radiosensitivity of lymphocytes from Alzheimer's disease patients
}

\author{
S E Tobi, J E Moquet, A A Edwards, D C Lloyd, R F Itzhaki
}

\begin{abstract}
We have examined chromosome aberrations in $\gamma$ irradiated ( $3 \mathrm{~Gy}$ ) lymphocytes from five patients with Alzheimer's disease (AD). In each case, the number of dicentrics was significantly higher than the number in irradiated lymphocytes from five age matched normal subjects, the mean value for AD cells being about $25 \%$ higher. There was no significant difference in number of acentrics between $A D$ and normal cells. Examination of the number of first, second, and third division metaphases, using fluorescence plus Giemsa staining, indicated that there was no difference in cycling time between $A D$ and normal cells, and that after irradiation both groups showed the same mitotic delay. The similarity of our findings to those of others with irradiated Down's syndrome cells (from adult patients) is discussed.
\end{abstract}

We have examined DNA repair in Alzheimer's disease (AD). The rationale for this is that lymphoblastoid cells from AD patients have been shown after $x$ irradiation to be less viable than those from age matched normal controls. ${ }^{1}$ Further, hypersensitivity of cells to certain DNA damaging agents has been detected in a number of neurological diseases; one of these, Down's syndrome (DS), is particularly relevant since all middle aged patients show the neuropathological characteristics of AD. Recently, fibroblasts from $A D$ patients have been found to be more sensitive than those from normal subjects to the alkylating agents $\mathrm{N}$-methyl-N'-nitro- $\mathrm{N}$-nitrosoguanidine (MNNG) ${ }^{2}$ and methyl methanesulphonate (MMS $),{ }^{3}$ as assayed by unscheduled DNA synthesis

Molecular Neurobiology Laboratory, Department of Optometry and Vision Sciences, UMIST, Manchester M60 10D.

S E Tobi, R F Itzhaki

National Radiological Protection Board, Chilton, Didcot, Oxon OX11 ORQ.

J E Moquet, A A Edwards, D C Lloyd

Correspondence to Dr Itzhaki.

Received for publication 19 December 1989.

Revised version accepted for publication 26 February 1990.
(UDS) or rate of strand rejoining. However, in the case of MMS, another study has indicated that the rate of rejoining in $\mathrm{AD}$ and normal cells is similar. ${ }^{4}$

Our previous studies on $\gamma$ irradiated peripheral lymphocytes have shown that cells from AD patients and age matched normal controls are equally proficient in UDS, ${ }^{5}$ in replication after PHA stimulation, ${ }^{6}$ and in rate of repair of single strand breaks (Smith and Itzhaki, submitted for publication). However, we decided to examine chromosome aberrations in AD cells after irradiation, because aberrations are probably a more sensitive reflection of inadequate or inaccurate repair of DNA, and because $x$ irradiated lymphocytes from DS patients show more chromosome aberrations than those from normal people.

\section{Material and methods \\ PATIENTS}

There were two males, aged 66 and 75 , and three females, age range 63 to 71 , who fulfilled the NINCDS-ADRDA (National Institute of Neurological and Communicative Disorders, Stroke-AD and Related Disorders Association) criteria for 'probable Alzheimer's disease'. In addition, they all had amnesia, visuospatial disorientation, and aphasia. The Hachinski ischaemia score was less than 4 in all cases. Single photon emission tomography showed posterior hemisphere reductions in uptake. No patient had familial AD (the criterion being that at least one close relative was affected). Medication for four patients consisted of: gammamil-proxalinecarnitine; naproxin-prolaxine-digoxin-folic acid; diuretics-fibagel; dithiopene-hydergene. The other patient received no medication.

Normal controls were three males, age range 62 to 70 , and two females, aged 61 and 76 . These were University colleagues, none of whom was receiving medication.

\section{PREPARATION OF SPECIMENS AND SCORING}

Slides were prepared according to standard procedures ${ }^{7}$ from triplicate samples of irradiated whole blood ( 3 Gy of Cobalt $-60 \gamma$ radiation) and of unirradiated controls. In each case, some cultures were terminated at 51 hours to score chromosomal aberrations and the 
remainder at 72 hours to assess cell cycle delay by measuring the number of first, second, and third division metaphases (M1, M2, and M3). Each slide was coded and stained by the fluorescence plus Giemsa method. ${ }^{8}$ For each subject at 0 and $3 \mathrm{~Gy}, 200$ first division metaphases from the 51 hour cultures were scored by the same person for dicentrics, centric rings, and excess acentric aberrations, and numbers of M1 and M2 metaphases were recorded also. Two hundred metaphases per subject were examined also from the $\mathbf{7 2}$ hour cultures to ascertain the numbers of $M 1, M 2$, and $M 3$ cells.

\section{Results}

Table 1 gives the age and sex of each normal person and $A D$ patient. The numbers of dicentrics, centric rings, and excess acentrics scored in 200 cells are given for irradiated ( $3 \mathrm{~Gy}$ ) and unirradiated samples. In all the latter, a total of 12 acentrics (six in the ADs and six in the normals), but no dicentrics or rings were seen. These background levels of aberrations are consistent with normal levels previously published. ${ }^{9}$ Similarly, the background (and irradiated) incidence of chromatid type aberrations was insignificant.

The distribution of radiation induced dicentric aberrations approximated closely to a Poisson distribution. Standard errors of the mean were, therefore, calculated on this basis (that is, for a Poisson, the mean is equal to the variance). However, acentrics showed overdispersion; their average ratio of variance to mean was $1 \cdot 33$. Average values of yield for the $\mathrm{AD}$ patients and the normal controls are also shown in table 1. It is clear that every AD patient has a higher sensitivity to dicentric induction than the normal controls, the mean $\mathrm{AD}$ value being greater by a factor of about $1 \cdot 25$. The difference between the means is significant $(p<0.001)$. However, AD patients do not seem to be more sensitive to the induction of

Table 1 Chromosomal aberrations in $G_{0}$ lymphocytes exposed to 3 Gy $\gamma$ irradiation (200 cells scored per subject).

\begin{tabular}{|c|c|c|c|}
\hline $\begin{array}{l}\text { Subjects } \\
\text { (sex, age) }\end{array}$ & Dicentrics & $\begin{array}{l}\text { Centric } \\
\text { rings }\end{array}$ & $\begin{array}{c}\text { Excess } \\
\text { acentrics }\end{array}$ \\
\hline $\begin{array}{lll}\text { AD1 } & \text { F } & 66 \\
\text { AD2 } & \text { F } & 63 \\
\text { AD3 } & \text { F } & 71 \\
\text { AD4 } & M & 66 \\
\text { AD5 } & M & 75\end{array}$ & $\begin{array}{l}122 \\
115 \\
103 \\
100 \\
103\end{array}$ & $\begin{array}{l}7 \\
3 \\
4 \\
6 \\
1\end{array}$ & $\begin{array}{r}136(3) \\
108(2) \\
90(1) \\
69(0) \\
67(0)\end{array}$ \\
\hline Mean (SEM) & $108 \cdot 6(4 \cdot 6)$ & & $94.0(10.0)$ \\
\hline $\begin{array}{lll}\text { N1 } & M & 66 \\
\text { N2 } & M & 66 \\
\text { N3 } & M & 70 \\
\text { N4 } & \text { F } & 76 \\
\text { N5 } & \text { F } & 61\end{array}$ & $\begin{array}{l}94 \\
83 \\
87 \\
82 \\
89\end{array}$ & $\begin{array}{l}9 \\
2 \\
6 \\
4 \\
4\end{array}$ & $\begin{array}{r}102(1) \\
87(1) \\
79(2) \\
106(2) \\
75(0)\end{array}$ \\
\hline Mean (SEM) & $87 \cdot 0(4 \cdot 2)$ & & $89 \cdot 8(5 \cdot 4)$ \\
\hline
\end{tabular}

*200 unirradiated cells per subject yielded only excess acentrics, shown in parentheses. acentrics: the ratio of the means is 1.05 and the difference between them is not statistically significant. Also, the total numbers of centric rings observed in the two groups were similar.

On the 51 hour slides, very few (average 3.6\%) unirradiated M2 cells were seen for either $A D$ or normal cells. An effect of radiation induced mitotic delay was discernible in both groups but since only $0.85 \%$ of cells were in $M 2$, analysis of the data was not taken further. Ratios of M1 to M2 suggest that cycling times of $\mathrm{AD}$ and normal cells are similar.

For the 72 hour cultures, table 2 shows the expected inter-donor variation in $M 1, M 2$, and $M 3$ values within both $A D$ and normal cells; however, the average numbers of $\mathrm{Ml}$ do not differ significantly between $A D$ and normal cells for either unirradiated or $3 \mathrm{~Gy}$ irradiated cells, suggesting again that the rate of cell cycling, and of entry into cycle, is similar for $\mathrm{AD}$ and normal cells. After irradiation, mitotic delay is quite evident and the average difference in number of $\mathrm{Ml}$ cells (38 for AD and 44 for normal controls) between unirradiated and irradiated is not significantly different, that is, radiation induced mitotic delay is similar in AD and normal cells.

\section{Discussion}

Our main finding is that $\gamma$ irradiated AD lymphocytes from each patient display significantly more dicentric chromosomal aberrations than cells from age matched, normal controls. On average, the increased yield after $3 \mathrm{~Gy}$ is about $25 \%$. In contrast, the levels of excess acentric fragments in the two groups are not significantly different. Our other finding (table 2) is that there appears to be no difference in cycling times between $\mathrm{AD}$ and normal cells, and after irradiation

Table 2 Numbers of cells at first, second, and third metaphase, at 72 hour post-stimulation (200 cells assessed per subject per dose).

\begin{tabular}{|c|c|c|c|c|c|c|}
\hline \multirow[b]{2}{*}{ Subjects } & \multicolumn{3}{|c|}{$0 \mathrm{~Gy}$} & \multicolumn{3}{|c|}{$3.0 \mathrm{~Gy}$} \\
\hline & M1 & M2 & M3 & M1 & M2 & M3 \\
\hline $\begin{array}{l}\text { AD1 } \\
\text { AD2 } \\
\text { AD3 } \\
\text { AD4 } \\
\text { AD5 }\end{array}$ & $\begin{array}{l}97 \\
83 \\
40 \\
84 \\
72\end{array}$ & $\begin{array}{r}80 \\
94 \\
118 \\
96 \\
92\end{array}$ & $\begin{array}{l}23 \\
23 \\
42 \\
20 \\
36\end{array}$ & $\begin{array}{r}128 \\
135 \\
94 \\
108 \\
102\end{array}$ & $\begin{array}{l}56 \\
58 \\
83 \\
80 \\
81\end{array}$ & $\begin{array}{r}16 \\
7 \\
23 \\
12 \\
17\end{array}$ \\
\hline Mean (SEM) & \multicolumn{3}{|c|}{$75 \cdot 2(9 \cdot 7)$} & \multicolumn{3}{|c|}{$113.4(7 \cdot 8)$} \\
\hline $\begin{array}{l}\text { N1 } \\
\text { N2 } \\
\text { N3 } \\
\text { N4 } \\
\text { N5 }\end{array}$ & $\begin{array}{l}50 \\
34 \\
76 \\
75 \\
59\end{array}$ & $\begin{array}{r}89 \\
116 \\
96 \\
91 \\
82\end{array}$ & $\begin{array}{l}61 \\
50 \\
28 \\
34 \\
59\end{array}$ & $\begin{array}{r}85 \\
79 \\
117 \\
126 \\
109\end{array}$ & $\begin{array}{r}89 \\
103 \\
63 \\
59 \\
67\end{array}$ & $\begin{array}{l}26 \\
18 \\
20 \\
15 \\
24\end{array}$ \\
\hline Mean (SEM) & \multicolumn{3}{|c|}{$58.8(7.9)$} & \multicolumn{3}{|c|}{$103 \cdot 2(9 \cdot 1)$} \\
\hline
\end{tabular}

100 metaphases were examined on each of two replicate slides from the 72 hour cultures to ascertain the numbers of $M 1, M 2$, and $M 3$ cells; since no significant difference was found within any pair of slides, values were combined. 
both groups show the same mitotic delay. Thus, the observed difference in aberration yields is unlikely to be the result of a difference in time of entry into cycle. Previous studies on spontaneous chromosome aberrations in $\mathrm{AD}$ cells have yielded conflicting results, some showing levels similar to those of normal cells, ${ }^{10}$ and others higher levels. " However, a definitive, large scale study ${ }^{12}$ showed that in female AD patients, but not in males, there was increased aneuploidy compared to age matched, normal controls, abnormalities being broadly similar to those seen in 20 year older normal persons. In the present study we have not examined aneuploidy; however, our unirradiated AD cells do not show significantly more spontaneous aberrations than age matched, normal controls. For DS lymphocytes also, the general consensus appears to be that the spontaneous aberration level resembles that of normal cells.

A few previous studies have used chemical agents rather than radiation to induce chromosome aberrations, specifically sister chromatid exchanges (SCE), in AD cells. After ethyl methanesulphonate treatment, ${ }^{13}$ no significant difference was found in SCE yields between AD and normal lymphocytes; after mitomycin $C$ (MMC), two studies found no difference in SCE yields, ${ }^{13}{ }^{1+}$ but another claimed to find an increase in AD lymphocytes. ${ }^{15}$

A study published while the present work was in progress has detected a higher level of aberrations in AD (and DS) lymphoblastoid cell lines than in normal ones after $\gamma$ irradiation ${ }^{16}$; however, the cells were irradiated in exponential phase, that is, at different stages of the cell cycle, with consequent variation in radiosensitivity, and so interpretation is difficult.

The increase of approximately $25 \%$ above normal in numbers of induced dicentrics in $\mathrm{AD}$ cells reported here is similar to that detected in cells from adult DS patients ${ }^{17-20}$ (and to those in two DS studies where ages were not given ${ }^{2122}$ ) after $x$ irradiation, and also after the radiomimetic, bleomycin..$^{23}$ In the case of DS children, the number of dicentrics after irradiation is about two fold greater than in normals. ${ }^{2+26}$ Irradiation in $\mathrm{G}_{0}$ does not increase the number of acentric aberrations in DS lymphocytes, ${ }^{25} 27$ just as we find for $\mathrm{AD}$ cells. The yields of centric rings were similar in the two groups and this conforms also with observations on DS lymphocytes. ${ }^{22}$ However, the numbers are low and so carry considerable error. Rings are observed in irradiated human lymphocytes typically at about $5 \%$ of the frequency of dicentrics, and so it is rarely possible to make statistical comparisons for this type of exchange aberration.

A similar rise in the number of dicentrics, but not acentrics, has been reported in lymphocytes from other radiosensitive syndromes, ${ }^{28}$ such as ataxia telangiectasia, Bloom's and Fanconi's syndromes (although doubts have been raised about this for $\left.\operatorname{ataxia}^{29}\right)$. Further, in DS cells from adults, as in our
AD cells, the proportion of cells at $M 1, M 2$, and $M 3$ is similar to that of normal cells, and after treatment (with bleomycin) progression to mitosis decreases to a similar extent.

Our previous studies have shown no significant difference in radiosensitivity between $\mathrm{AD}$ and normal lymphocytes. Thus, our findings parallel those on $\mathrm{G}_{0}$ Down's syndrome lymphocytes, in which there is no conclusive evidence of a defect at the molecular level, although a higher level of chromosome aberrations has been detected after $x$ irradiation. Our present study therefore points to yet another similarity between $\mathrm{AD}$ and $\mathrm{DS}$, in addition to the neuropathological changes and the involvement of chromosome 21 .

This work was initiated under grants from the Mental Health Foundation and the Sir Jules Thorn Charitable Trust and is now funded by Research into Ageing. We also thank Dr P Goulding and Mr R Oojageer for taking blood samples, Dr D Neary for assessment of patients, and Professor A Tallentire for use and calibration of the Co $\gamma$ ray source.

1 Robbins JH, Otsuka F, Tarone RE, et al. Radiosensitivity in Alzheimer disease and Parkinson disease. Lancet 1983;i:468-9.

$2 \mathrm{Li} \mathrm{JC,} \mathrm{Kaminskas} \mathrm{E}$. Deficient repair of DNA lesions in Alzheimer's disease fibroblasts. Biochem Biophys Res Commun 1985;129:733-8.

3 Robison SH, Scott Munzer J, Tandan R, et al. Alzheimer's disease cells exhibit defective repair of alkylating agent-induced DNA damage. Ann Neurol 1987;21:250-8.

4 Kinsella TJ, Dobson PP, Fornace AJ, et al. Al \%heimer's disease fibroblasts have normal repair of $\mathrm{N}$-methyl- $\mathrm{N}^{\prime}$-nitro-N-nitrosoguanidine-induced DNA damage determined by the alkaline elution technique. Biochem Biophys Res Commun 1987;149: 355-61.

5 Smith TAD, Neary D, Itzhaki RF. DNA repair in lymphocytes from young and old individuals and from patients with Alzheimer's disease. Mutat Res 1987;184:107-12.

6 Smith TAD, Itzhaki RF. Radiosensitivity of lymphocytes from patients with Alzheimer's disease. Mutat Res 1989;217:11-17.

7 Lloyd DC, Prosser JS, Purrott RJ. The study of chromosome aberration yield in human lymphocytes as an indicator of radiation dose: revised techniques. Chilton: National Radiological Protection Board, 1982:NRPB-M70.

8 Perry $P$, Wolff S. New Giemsa method for the differential staining of sister chromatids. Nature 1974;251:156-8.

9 Lloyd DC, Purrott RJ, Reeder EJ. The incidence of unstable chromosome aberration in peripheral blood lymphocytes from unirradiated and occupationally exposed people. Mutat Res 1980;72:523-32.

10 Sulkava R, Rossi L, Knuutila S. No elevated sister chromatid exchange in Alzheimer's disease. Acta Neurol Scand 1979;59: 156-9.

11 Nordenson I, Adolfsson R, Beckman G, et al. Chromosomal abnormality in dementia of Alzheimer type. Lancet 1980; 481-2.

12 Buckton KE, Whalley LJ, Christie JE, Lee M. Chromosome changes in Alzheimer's presenile dementia. I Med Genet 1983;20:46-51.

13 Das RK. Mitomycin C and ethyl methanesulphonate-induced sister-chromatid exchanges in lymphocytes from individuals with Alzheimer's pre-senile dementia. Mutat Res 1986;173: 127-30.

14 Matsuyama SS, Fu TK. Sister chromatid exchanges and dementia of the Alzheimer type. Neurobiol Aging 1988;9:405-8.

15 Fischman HK, Reisberg B, Albur P, Rainer JD. Sister chromatid exchanges and cell cycle kinetics in Alyheimer's disease. Biol Psychol 1984;19:319-27. 
16 Lavin MF, Bates $P$, Le Poidevin P, Chen PC. Normal inhibition of DNA synthesis following $\gamma$-irradiation of radiosensitive cel lines from patients with Down's syndrome and Alzheimer's disease. Mutat Res 1989;218:41-7.

17 Evans HJ, Adams A. X-ray induced chromosome aberrations in human lymphocytes irradiated in vitro. The influence of exposure conditions, genotype and age on aberration yields. In: Advances in Radiation Research. Biology \& Medicine Vol 1. London: Gordon \& Breech, 1973:335-8.

18 Lambert B, Hansson K, Bui TH, et al. DNA repair and frequency of X-ray and u.v.-light induced chromosome aberrations in leukocytes from patients with Down's syndrome. Ann Hum Genet 1976;39:293-302.

19 Morten JEN, Harnden DG, Taylor AMR. Chromosome damage in G X-irradiated lymphocytes from patients with hereditary retinoblastoma. Cancer Res 1981;41:3635-8.

20 Shafik HM, Au WW, Leator MS. Chromosomal radiosensitivity of Down syndrome lymphocytes at different stages of the cell cycle. Hum Genet 1988;78:71-5.

21 Holmberg $M$. No interaction between ultraviolet and $\mathrm{X}$ irradiation on chromosome aberrations in cells with trisomy 21. Nature 1974;249:448-9.
22 Preston RJ. X-ray induced chromosome aberrations in Down lymphocytes: an explanation of their increased sensitivity. Environ Mutagen 1981;3:85-9.

23 Vijayalaxmi, Evans HJ. Bleomycin-induced chromosomal aberrations in Down's syndrome lymphocytes. Mutat Res 1982;105: 107-13.

24 Sasaki MS, Tonomura A, Matsubara S. Chromosome constitution and its bearing on the chromosomal radiosensitivity in man. Mutat Res 1970;10:617-33.

25 Higurashi $M$, Conen PE. In vitro chromosomal radiosensitivity in patients and in carriers with abnormal non-Down's syndrome karyotypes. Pediatr Res 1972;6:514-20.

26 Morimoto K, Kaneko T, Iijima K, Koizumi A. Proliferative kinetics and chromosome damage in trisomy 21 lymphocyte cultures exposed to $\gamma$-rays and bleomycin. Cancer Res 1984;44: 1499-504.

27 Sasaki MS, Tunomura A. Chromosomal radiosensitivity in Down's syndrome. Fpn f Hum Genet 1969;14:81-92.

28 Higurashi $M$, Conen PE. In vitro chromosomal radiosensitivity in "chromosomal breakage syndromes." Cancer 1973;32:380-3.

29 Bender MA, Rary JM, Kale RP. Chromosomal radiosensitivity in ataxia telangiectasia lymphocytes. Mutat Res 1985;150:277-82. 